\title{
EDITORIAL
}

\section{Obstacles during implementing the integrated program in the faculties of medicine:}

\author{
Personal experience \\ Prof. Abdelrahman Mohammed Abdelmottaleb Ismail \\ Medical Physiology Department, Al-Azhar Faculty of M edicine
}

Implementing the new integrated-system based curriculum is never an easy task. Obstacles we face, especially on launching this system, are numerous and hard to deal with. We can classify these obstacles into 4 main categories.

\section{Staff members:}

I remember the first time when we were asked to implement this system; how we were shocked. Most of the staff members tried to show how bad is this system, not only for the students but also for the health of the people. When we realized that implementing was mandatory and we cannot evade it, we spent one complete year to plan and design the curriculum of this undesired system, but this was not even enough to change our convections. On starting this system, we did our best to help those unlucky students by teaching them much more than what was actually agreed upon. This what face now from our colleagues who didn't pass through this experience.

\section{1) Belief: New system is wrong}

Resistance of the staff members is by far the most difficult problem we face. Many of the staff members are sincere and they believe that the new system is wrong and it is impossible not to teach the curriculum that was taught maybe for more than 100 years. I believe that those sincere people are the most difficult ones regarding resistance.

\section{2) Insufficient number of staff}

Staff members in some departments are too few. The new system decreased markedly the number of lectures, and teaching depends mainly on small group discussion, practical lessons, and other activity. So, instead of one lecture given in one hour by one tutor, for example in AlAzhar Faculty of Medicine where we have 25 small groups of students; we need 25 tutors, everyone has to teach 2 hours, i.e. the lesson, which is covered in one-hour lecture, is covered now in 50 hours in small group discussion. 


\section{3) Unknown is an enemy}

Many staff members are not sure that they are able to cope with the new system. For decades, they used to teach lectures and practical or clinical lessons only, they are not sure that they can share in the new methods of teaching such as problem-based learning. They are also asked to reduce the contents of the curriculum, but they don't know what to keep and what to remove. Because of their lack of knowledge about the new system they resist it and try to prevent its proper teaching.

\section{4) Inflexibility}

"We were taught under the ordinary system, which was used to graduate all the working physicians. We are good as well as our students. So why is The change?". Most of the senior staff members use similar words to express their beliefs. They refuse to attend the held workshops which are designed to explain the new system for them, and if they attend they try to fail these workshops.

\section{5) Against their benefits}

Some staff members enjoy living in their own comfortable zones. They spent most of their lives as tutors in repeating the same topics, in the same lectures in the same time and in the same day of the same week every year. They arranged their life according to a simple fixed schedule, which is not the case in the new system in which timetable is changing every week. Some of them may have different jobs in different places and their income maybe markedly affected by the new system.

\section{6) Trying to transfer their beliefs to students}

Resistance could be announced and clear, but for many staff members they claim that they comply with the new system, but actually they try to destruct it from inside. As a role most of them try to change any teaching activity into lectures. The majority don't finish the lecture in the allocated 50 minutes and con nue to use the me in between the lectures. Some of them change the small group discussion into oral exams. They usually try to convince the students that they will be ignorant and inefficient, and for sure they will not succeed in their career as physicians if they don't study according to the old curriculum.

\section{II) Technicians and other employees:}

\section{1) Inability to cope with the new system}

At the very beginning of the last academic year when we started implementing the new system, and according to the official timetable during the first week, the student went, to attend a practical lab. The responsible technician told them that there is no labs as usual during the first week of the year. The students simply believed him and left. In the second week, they went to the same department looking for the assigned rooms for small group discussion. Again the technician told them that there is no such activity and again the students left. The technician didn't try to resist the system, but he told the students what knows. This revealed 2 problems: 
A) We may plan everything properly and make decision to implement but the communication was inefficient. B) Any employee in the faculty can fail the new system.

\section{2) Unpaid extra work}

Although the number of employees is generally too much in Egypt, yet there are some jobs which suffer from shortage of employees as in some sections in our Faculty. Our employees always complain from doing unpaid extra work. This explains why they are not happy on doing the necessary work for the new system and they always try to avoid these duties.

\section{III) Students:}

\section{1) Anxiety}

The first patch of students in the new system were both very enthusiastic and anxious. The University is quite different from their secondary schools, and the language of teaching is not easy for them. However, they had a peculiar problem which is the presence of a new unknown system. Nobody knows about it; even their tutors.

\section{2) Senior students}

As usual, Gunior Students try to gain from the experience of the senior student. In this particular situation, on applying the new system for the first time, senior students gave them a lot of disastrous information and advices, which increase their suffering and anxiety.

\section{3) Rumors}

Rumors ane easily transmitted among the new students. With much ignorance and lack of necessary informa on and guidance, 50 students ane ready to believe anything about their studies, books, exams, .etc.

\section{4) Disappointment}

With all the previous difficulties, while living alone far from their families in mostly unsuitable places, many students quickly became disappointed and some of them preferred to join another faculty.

\section{IV) Money:}

A new system came with new requirements. Without enough and reasonable Sach Cepuirenr Ents, it would be impossible to fulfill the needs of implementing it.

\section{1) Administration and Costs}

We are in a bad need of new administrative system for registering the students and following them through their study. This means an efficient software with many computers and trained employees and staff members. 


\section{2) Internet}

Internet is a must for the new system. The Faculty should provide all its buildings with free efficient fast Wi Fi. If not; the students will spend more time outside the faculty. They will also have to spend money to gain access to the net, which could be too much for most of them.

\section{3) Library}

An active efficient library is always needed. This means having suitable comfortable place with the last editions of the most important textbooks, with internet, computers, photocopiers, and printers, and above all with specialized helpful personnel.

\section{4) Unequipped teaching room}

Many times than not, in Al-Azhar Faculty of Medicine, we need 25 rooms for the ac vi es of the small groups at the same time for the first year only. This number may be doubled every year. Each room should have enough space, enough chairs for the students, suitable table, computer, projectors, screens, boards, flipcharts, and markers.

\section{5) Problem of too much exams}

During the ? rst semester we had more than 20 exam. This necessitates a lot of personnel and equipment. With the usual shortage of paper and lack of personnel; we face a lot of problems. New faster photocopier machines are required. It is also crucial to have machines that correct the exams. M any exams were delayed because the invigilators ane not available on time.

Finally; staff members responsible for designing and implementing the new program should never be disappointed by the aforementioned problems. By time, resistance will decrease, and, little by little, the system will progress normally. They should be both rigid and flexible. They should never accept any trial to violate the rules of the new system, However, they should understand the motives behind the resistant staff members and they should not stress on unintended mistakes. I have 3 advices for those responsible persons; pa ence, pa ence and patience. 